\title{
The Plasma Sugar, Free Fatty Acid, Cortisol, and Growth Hormone Response to Insulin, and the Comparison of This Procedure with Other Tests of Pituitary and Adrenal Function. II. In Patients with Hypothalamic or Pituitary Dysfunction or Anorexia Nervosa *
}

\author{
J. Landon, † F. C. Greenwood, † T. C. B. Stamp,§ and V. Wynn \\ (From the Protein Chemistry Section, Imperial Cancer Research Fund, Lincoln's Inn Fields, \\ and the Alexander Simpson Laboratories for Metabolic Research, Department of \\ Chemical Pathology, St. Mary's Hospital, London, England)
}

Data have previously been presented suggesting that a test based on the plasma cortisol response to insulin-induced hypoglycemia may be valuable in the diagnosis of patients with suspected hypothalamic or pituitary dysfunction (1). Further, the increased secretion of growth hormone that normally follows the injection of insulin (2-4) has been shown to be mediated via the hypothalamus (5) and to be impaired in children and adults with hypopituitarism $(2,4,6,7)$. These studies, which have been limited to small groups of patients, have not involved the simultaneous determination of both the plasma cortisol and the growth hormone response and have not been related to other tests of pituitary or adrenal function.

The object of the present investigation was to compare the plasma cortisol and growth hormone responses to insulin in patients with disorders of hypothalamic or pituitary function with the results obtained in control subjects, and to study the relative value of this procedure in relation to other tests of pituitary and adrenal function. The free fatty acid (FFA) response to insulin was followed in several patients because of the important role assigned to the pituitary in regulating their rate of turnover and plasma level (8-10). Finally, patients with anorexia nervosa were studied because

* Submitted for publication September 21, 1965; accepted December 2, 1965.

+ This work was carried out during the tenure of a Ciba Research Fellowship.

¥ Address requests for reprints to Dr. F. C. Greenwood, Imperial Cancer Research Fund, Lincoln's Inn Fields, London, W.C.2, England.

$\S$ Recipient of a Medical Research Council grant. of the occasional difficulty in differentiating clinically this condition from hypopituitarism (11).

\section{Methods}

Thirty-eight tests were performed in 34 patients whose clinical data are summarized in Table $\mathrm{I}$.

Diagnosis was based on the clinical findings, and in patients with pituitary tumors, on radiological evidence of an enlarged sella turcica. The type of tumor was confirmed histologically, after hypophysectomy, except in Patients 1, 2, 13, and 14. Three patients (No. 27 to 29) were considered to have a hypothalamic rather than a primary pituitary disorder because they had diabetes insipidus, which is seldom encountered in pituitary dysfunction other than after hypophysectomy (12), and because they had secondary adrenocortical insufficiency despite a normal adrenal response to the infusion of lysine vasopressin. The use of lysine vasopressin in helping to differentiate hypothalamic from pituitary causes of secondary adrenocortical insufficiency has been described previously (13). Patient 27 had initially presented with cutaneous and other manifestations of sarcoidosis, after which he developed diabetes insipidus and secondary hypogonadism. Patient 28 was a 17-year-old girl who had not grown since the age of 11 , when she had developed diabetes insipidus during a probable attack of encephalitis. In addition she had primary amenorrhea and an absence of any secondary sexual characteristics. The etiology of the presumed hypothalamic defect in Patient 29 was not known. He had always been smaller than his contemporaries and had presented with the signs and symptoms of secondary hypogonadism.

At the time the tests were performed some patients wcre receiving replacement therapy. Thus Patients 5, 6, $12,13,14,17,19,21,22$, and 24 were receiving 0.2 or 0.3 $\mathrm{mg}$ of L-thyroxine daily, Patients $5,6,12,14,19,21$, and 22 were receiving 20 or $30 \mathrm{mg}$ of cortisol daily, and Patient 27 was receiving $15 \mathrm{mg}$ daily of methyl testosterone.

The intravenous injection of insulin was performed 
with the same safeguards, and the plasma sugar, FFA, cortisol, and growth hormone levels were determined, as described previously (14). Patients receiving replacement therapy were given $\mathrm{x}$-thyroxine or cortisol or both 14 to 16 hours before starting the test. All patients were injected intravenously with $0.10 \mathrm{U}$ of insulin per $\mathrm{kg}$ body weight with the exception of the four patients with untreated acromegaly, who received $0.30 \mathrm{U}$ per $\mathrm{kg}$. These doses of insulin were used in an attempt to reproduce the plasma sugar response found in control subjects injected with $0.15 \mathrm{U}$ per $\mathrm{kg}$, and the interpretation of the results obtained in the present study has been based on comparison with those found in these control subjects and reported previously (14). The majority of patients experienced drowsiness, increased sweating, and palpitations during the test, but none experienced severe side effects or required termination of the test by the intravenous injection of glucose.

For comparative purposes the indexes studied included the levels of plasma sugar, FFA, cortisol, and growth hormone in fasting patients; the degree of insulin sensitivity as related to the plasma sugar and to the FFA response; and the maximal cortisol and growth hormone levels found during the test and their maximal increment above the fasting level. The insulin sensitivity of each patient in relation to plasma sugar and FFA changes was assessed on the basis of the lowest levels reached and of their recovery index. This index is the sum of the $60-, 90-$, and 120 -minute values expressed as a percentage of the resting level and is a measure of the rate of return of plasma sugar and FFA to preinsulin values.

The patients were investigated in a metabolic unit, and in addition to the insulin studies, adrenal function was investigated by determining their plasma cortisol response to adrenocorticotropin (ACTH) and pituitaryadrenal function by determining the urinary 17-hydroxycorticosteroid (17-OHCS) response to metyrapone (2-methyl-1,2-bis(3-pyridy1)-propan-1-one). Highly purified porcine $\mathrm{ACTH}^{1}$ was infused intravenously at 10 IU per hour, a rate greatly in excess of that required to produce a maximal adrenocortical response (15). The metyrapone tests were performed over a 4-day period, during which the 24-hour excretion values of 17 OHCS were determined. Days 1 and 2 were taken as a control period. On day 3 the patient received $4.5 \mathrm{~g}$ of metyrapone ( $750 \mathrm{mg}$ each 4 hours for 24 hours), and the response was assessed as the maximal urinary 17-OHCS increment on either day 3 or day 4 above the mean value of the 2 control days. Urinary 17-OHCS were determined as described previously (16).

In addition a qualitative assessment of the patient's ability to secrete thyroid-stimulating hormone (TSH), gonadotropins, and antidiuretic hormone (ADH) was attempted. Thyroid function before any thyroxine replacement therapy was assessed on the basis of the clinical findings, pulse rate during sleep, basal metabolic rate, electrocardiograph and electroencephalograph recordings, the level of circulating protein-bound iodine, and the neck

1 Organon, West Orange, N. J. uptake of ${ }^{181} I$ with and without the prior administration of TSH. The assessment of gonadotropin production was based on the clinical history, the presence or absence of body and facial hair, and on gonadotropin excretion The integrity of the $A D H$ mechanism was determined by studying whether the patient could respond to fluid deprivation with a fall in the urinary minute volume to below $0.6 \mathrm{ml}$ and an increase of the urine osmolarity to above $700 \mathrm{mOsm}$ per $\mathrm{L}$. A detailed account of the results of these studies in a larger group of patients with hypothalamic or pituitary dysfunction will be published separately.

\section{Results}

The resting plasma sugar, $F F A$, cortisol, and growth hormone values after an overnight fast

The mean values of two to eight separate determinations in each patient are compared in Table I with those found in control subjects (14).

Compared with the controls the mean plasma sugar value of $111 \pm 11.8 \mathrm{mg}$ per $100 \mathrm{ml}$ in fasting patients with untreated acromegaly was significantly high $(p<0.01)$ and the mean value of $73 \pm 10.5 \mathrm{mg}$ per $100 \mathrm{ml}$ in fasting patients with anorexia nervosa significantly low $(p<0.01)$. The mean plasma sugar concentration in the remaining patients who had hypothalamic or pituitary hypofunction was $89 \pm 9.9 \mathrm{mg}$ per $100 \mathrm{ml}$, which was not significantly different from the mean of the control group. Individually only one of the patients (No. 12) had a plasma sugar level that lay below the normal range. Another ( $\mathrm{Pa}$ tient 14) had initially presented with attacks of hypoglycemia precipitated by exertion and had had a mean resting level of $64 \mathrm{mg}$ per $100 \mathrm{ml}$ before being started on replacement therapy with L-thyroxine and cortisol.

No significant differences were found between the mean fasting FFA levels in the patients and in control subjects.

The patients with untreated acromegaly had normal resting levels of plasma cortisol, whereas the mean value of $20.5 \pm 1.0 \mu \mathrm{g}$ per $100 \mathrm{ml}$ in patients with anorexia nervosa was significantly higher $(p<0.001)$ than that found in control subjects. Thirteen of the remaining patients had plasma cortisol levels below the normal range, including three (Patients 10,13, and 14) with pituitary tumors, six (Patients 5, 6, 7, 12, 19, and 20) who had had a hypophysectomy, the two patients with Sheehan's syndrome (Patients 24 and 25), one (Patient 26) with an isolated defect of ACTH 
TABLE I

Clinical data and fasting levels of plasma sugar, FFA, cortisol, and growth hormone

\begin{tabular}{|c|c|c|c|c|c|c|c|}
\hline \multirow[b]{2}{*}{$\begin{array}{l}\text { Patient } \\
\text { no. }\end{array}$} & \multirow[b]{2}{*}{ Sex } & \multirow[b]{2}{*}{ Age } & \multirow[b]{2}{*}{ Diagnosis } & \multicolumn{4}{|c|}{ Fasting plasma levels* } \\
\hline & & & & Sugar & FFA & Cortisol & $\begin{array}{r}\text { Growth } \\
\text { hormone }\end{array}$ \\
\hline 1 & $\mathbf{M}$ & 47 & Acromegaly & $\begin{array}{l}m g / 100 m l \\
105\end{array}$ & $\begin{array}{c}\mu E q / L \\
780\end{array}$ & $\begin{array}{l}\mu g / 100 \mathrm{ml} \\
9.1\end{array}$ & $\begin{array}{c}m \mu g / m l \\
50\end{array}$ \\
\hline 2 & $\mathbf{M}$ & 44 & Acromegaly & 112 & 630 & 14.7 & 99 \\
\hline 3 & $\mathbf{M}$ & 40 & Acromegaly & 100 & 850 & 11.8 & 80 \\
\hline 4 & $\mathbf{F}$ & 53 & Acromegaly & 126 & 680 & 8.2 & 65 \\
\hline 5 & $\mathbf{M}$ & 35 & $\begin{array}{l}\text { Posthypophysectomy, } \\
\text { acromegaly }\end{array}$ & 79 & 450 & 2.8 & 4.8 \\
\hline 6 & $\mathbf{F}$ & 62 & $\begin{array}{l}\text { Posthypophysectomy, } \\
\text { acromegaly }\end{array}$ & 100 & 550 & 1.7 & 1.5 \\
\hline 7 & $\mathbf{F}$ & 43 & $\begin{array}{l}\text { Posthypophysectomy, } \\
\text { acromegaly }\end{array}$ & 89 & 450 & 5.2 & 5.8 \\
\hline 8 & $\mathbf{M}$ & 61 & Chromophobe adenoma & 100 & & 9.9 & $<1$ \\
\hline 9 & $F$ & 66 & Chromophobe adenoma & 95 & & 20.1 & $<1$ \\
\hline 10 & $\mathbf{M}$ & 60 & Chromophobe adenoma & 83 & & 6.7 & $<1$ \\
\hline 11 & $\mathbf{M}$ & 56 & Craniopharyngioma & 96 & & 12.7 & $<1$ \\
\hline $12(\mathrm{a})$ & $\mathrm{M}$ & 16 & Chromophobe adenoma & 70 & & 7.6 & $<1$ \\
\hline 13 & $\mathbf{M}$ & 58 & Probable chromophobe adenoma & 75 & 640 & 2.1 & $<1$ \\
\hline 14 & $\mathbf{M}$ & 60 & Probable chromophobe adenoma & 100 & 610 & 4.7 & $<1$ \\
\hline $15(\mathrm{a})$ & $\mathbf{F}$ & 63 & Chromophobe adenoma & 83 & & 9.6 & $<1$ \\
\hline 16 & M & 73 & Chromophobe adenoma & 89 & & 8.2 & $<1$ \\
\hline $12(b)$ & $\mathbf{M}$ & 16 & $\begin{array}{l}\text { Posthypophysectomy, } \\
\text { chromophobe adenoma }\end{array}$ & 83 & 420 & 1.6 & $<1$ \\
\hline $15(b)$ & $\mathrm{F}$ & 63 & $\begin{array}{l}\text { Posthypophysectomy, } \\
\text { chromophobe adenoma }\end{array}$ & 90 & & 19.6 & $<1$ \\
\hline 17 & $\mathbf{F}$ & 34 & $\begin{array}{l}\text { Posthypophysectomy, } \\
\text { chromophobe adenoma }\end{array}$ & 85 & & 9.5 & $<1$ \\
\hline 18. & $M$ & 16 & $\begin{array}{l}\text { Posthypophysectorny, } \\
\text { craniopharyngioma }\end{array}$ & 92 & 710 & 13.8 & $<1$ \\
\hline 19 & $\mathbf{F}$ & 37 & $\begin{array}{l}\text { Posthypophysectomy, } \\
\text { chromophobe adenoma }\end{array}$ & 81 & 590 & 5.2 & $<1$ \\
\hline 20 & $\mathbf{M}$ & 54 & $\begin{array}{l}\text { Posthypophysectomy, } \\
\text { chromophobe adenoma }\end{array}$ & 91 & & 13.3 & $<1$ \\
\hline 21 & $\mathbf{M}$ & 18 & $\begin{array}{l}\text { Posthypophysectomy, } \\
\text { craniopharyngioma }\end{array}$ & 95 & 740 & 12.0 & $<1$ \\
\hline 22 & $\mathbf{F}$ & 60 & $\begin{array}{l}\text { Posthypophysectomy, } \\
\text { chromophobe adenoma }\end{array}$ & 120 & & 15.2 & 2.6 \\
\hline 23 & $\mathbf{M}$ & 24 & $\begin{array}{l}\text { Posthypophysectomy, } \\
\text { chromophobe adenoma }\end{array}$ & 98 & & 21.0 & 2.8 \\
\hline 24 & $\mathrm{~F}$ & $32 *$ & Sheehan's syndrome & 79 & 750 & 3.8 & $<1$ \\
\hline 25 & $\mathrm{~F}$ & 23 & Sheehan's syndrome & 83 & 260 & 0.6 & $<1$ \\
\hline 26 & $\mathbf{F}$ & 32 & $\begin{array}{l}\text { Isolated defect of corticotropin } \\
\text { production }\end{array}$ & 90 & & 3.5 & 4.3 \\
\hline 27 & $\mathbf{M}$ & 40 & $\begin{array}{l}\text { Hypothalamic dysfunction, } \\
\text { sarcoidosis }\end{array}$ & 90 & 700 & 11.0 & 1.3 \\
\hline 28 & $\mathbf{F}$ & 17 & Hypothalamic dysfunction & 81 & 620 & 8.4 & $<1$ \\
\hline 29 & $\mathbf{M}$ & 51 & Hypothalamic dysfunction & 94 & & 4.1 & $<1$ \\
\hline 30 & $\mathbf{F}$ & 17 & Anorexia nervosa & 60 & & 20.7 & 2.7 \\
\hline 31 & F & 19 & Anorexia nervosa & 81 & & 23.2 & 13.1 \\
\hline 32 & M. & 42 & Anorexia nervosa & 64 & & 17.6 & 7.3 \\
\hline 33 & $\mathrm{~F}$ & 19 & Anorexia nervosa & 82 & & 20.1 & 3.0 \\
\hline \multirow[t]{2}{*}{34} & $\mathbf{F}$ & 47 & Anorexia nervosa & 80 & & 19.5 & 11.0 \\
\hline & & & $\begin{array}{r}\text { Mean } \\
\text { Control subjects SD } \\
\text { Range }\end{array}$ & $\begin{array}{c}94 \\
8.2 \\
75-105\end{array}$ & $\begin{array}{c}610 \\
121 \\
370-880\end{array}$ & $\begin{array}{c}12.7 \\
2.9 \\
6.8-20.2\end{array}$ & $\begin{array}{c}2.6 \\
3.9 \\
<1-20.4\end{array}$ \\
\hline
\end{tabular}

* Each value represents the mean of from two to eight separate determinations in each patient. 
TABLE II

The plasma sugar, FFA, cortisol, and growth hormone response to insulin (0.30 U per $\mathrm{kg})$ in patients with untreated acromegaly

\begin{tabular}{|c|c|c|c|c|c|c|c|c|c|}
\hline \multirow[b]{2}{*}{ Patient no. } & & \multicolumn{2}{|c|}{ Plasma sugar } & \multicolumn{2}{|c|}{ Plasma FFA } & \multicolumn{2}{|c|}{ Plasma cortisol } & \multicolumn{2}{|c|}{ Plasma growth hormone } \\
\hline & & Minimum* & $\begin{array}{c}\text { Recovery } \\
\text { indext }\end{array}$ & Minimum* & $\begin{array}{c}\text { Recovery } \\
\text { indext }\end{array}$ & Maximum & $\underset{\text { increment }}{\text { Maximal }}$ & Maximum $\ddagger$ & $\underset{\text { increment }}{\text { Maximal }}$ \\
\hline \multirow{3}{*}{$\begin{array}{l}1 \\
2 \\
3 \\
4\end{array}$} & & $\stackrel{\mathrm{mg} /}{100 \mathrm{ml}}$ & & $\mu E q / L$ & & $\mu \mathrm{g} / 100 \mathrm{ml}$ & & $m \mu g / m l$ & \\
\hline & & $\begin{array}{l}35 \\
56 \\
40 \\
42\end{array}$ & $\begin{array}{l}155 \\
226 \\
247 \\
168\end{array}$ & $\begin{array}{l}500 \\
190 \\
390 \\
360\end{array}$ & $\begin{array}{l}372 \\
283 \\
194 \\
178\end{array}$ & $\begin{array}{l}23.8 \\
26.8 \\
28.6 \\
24.5\end{array}$ & $\begin{array}{r}13.0 \\
13.4 \\
7.9 \\
15.9\end{array}$ & $\begin{array}{r}259 \\
146 \\
79 \\
56\end{array}$ & $\begin{array}{r}209 \\
61 \\
0 \\
0\end{array}$ \\
\hline & $\begin{array}{l}\text { Mean } \\
\text { SD }\end{array}$ & $\begin{array}{r}43 \\
9\end{array}$ & $\begin{array}{r}199 \\
47\end{array}$ & $\begin{array}{l}360 \\
181\end{array}$ & $\begin{array}{r}257 \\
89\end{array}$ & $\begin{array}{r}25.9 \\
4.6\end{array}$ & $\begin{array}{r}12.6 \\
3.4\end{array}$ & $\begin{array}{r}135 \\
91\end{array}$ & $\begin{array}{l}68 \\
99\end{array}$ \\
\hline $\begin{array}{l}28 \text { control } \\
\text { subjects given } \\
0.15 \mathrm{U} / \mathrm{kg}\end{array}$ & $\begin{array}{l}\text { Mean } \\
\text { SD } \\
\text { Range }\end{array}$ & $\begin{array}{r}31 \\
9 \\
18- \\
53\end{array}$ & $\begin{array}{l}211 \\
36 \\
116- \\
292\end{array}$ & $\begin{array}{r}330 \\
90 \\
140- \\
480\end{array}$ & $\begin{array}{r}286 \\
67 \\
188- \\
403\end{array}$ & $\begin{array}{r}28.1 \\
5.0 \\
21.7- \\
37.6\end{array}$ & $\begin{array}{r}15.4 \\
4.8 \\
7.7- \\
24.2\end{array}$ & $\begin{array}{l}37.4 \\
25.2 \\
15.1- \\
121.1\end{array}$ & $\begin{array}{l}35.0 \\
24.9 \\
13.7- \\
118.6\end{array}$ \\
\hline
\end{tabular}

* The minimal value 0 to 120 minutes after the injection of insulin.

$\uparrow$ The sum of the values found 60, 90, and 120 minutes after the injection of insulin expressed as a percentage of the resting value.

$\ddagger$ The maximal value 0 to 120 minutes after the injection of insulin.

$\$$ The maximal value 0 to 120 minutes after the injection of insulin less the resting value.

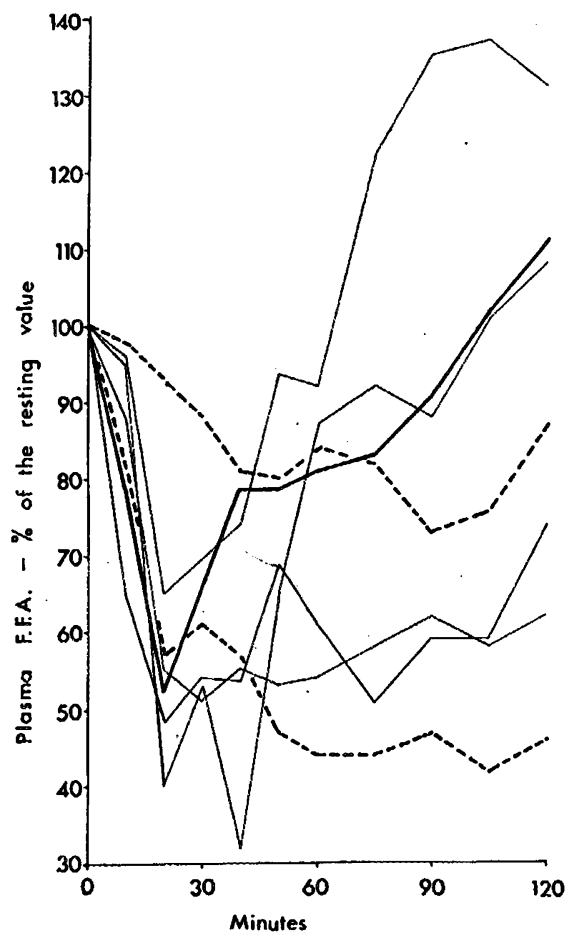

Fig. 1. The plasma FFA response to insulin expressed as a percentage of the resting value. Mean response in control subjects given $0.15 \mathrm{U}$ of insulin per $\mathrm{kg}$ (- - , responses in four patients with untreated acromegaly given $0.30 \mathrm{U}$ per $\mathrm{kg}$ ( $\longrightarrow$ ), and range of responses in patients with hypopituitarism given 0.10 $\mathrm{U}$ per $\mathrm{kg}$ (between the two dotted lines). production, and one (Patient 29) with hypothalamic dysfunction.

Both the group of patients with untreated acromegaly and the group with anorexia nervosa (in which the mean level was $7.4 \pm 4.7 \mathrm{~m} \mu \mathrm{g}$ per $\mathrm{ml}$ ) had significantly elevated resting growth hormone levels as compared with the control group ( $\mathrm{p}<$ 0.001 ). The patients with acromegaly who had been treated surgically had detectable levels of growth hormone that were, however, markedly lower than the values found in the untreated group. Only one of the three patients with hypothalamic dysfunction and three of the 18 remaining patients with pituitary hypofunction had detectable levels of growth hormone after overnight fasting.

The plasma sugar, $F F A$, cortisol, and growth hormone responses to insulin

In patients with untreated acromegaly. A summary of the results obtained in four patients with untreated acromegaly after the intravenous injection of $0.30 \mathrm{U}$ per $\mathrm{kg}$ of insulin is compared in Table II with the results found in 28 control subjects given $0.15 \mathrm{U}$ per $\mathrm{kg}$ (14).

The patients showed marked insulin resistance in relation to their plasma sugar response. Thus the mean minimum of the plasma sugar was higher 
and the recovery index lower than the mean values found in the control group given one-half the dose of insulin. This was associated with a normal plasma cortisol response in all four patients. There was considerable disparity in their plasma FFA response to insulin (Figure 1), which appeared to be related to the presence, or absence, of a growth hormone response. Thus in Patient 1 , in whom the maximal growth hormone increment was above the normal range, the recovery index of the plasma FFA was high, whereas in Patients 3 and 4 in whom there was no rise in growth hormone levels during the test, plasma FFA levels failed to increase from the nadir. Patient 2 had normal growth hormone and FFA responses to insulin.
In patients with hypothalamic or pituitary hypofunction. The results obtained in this group of patients after the injection of $0.10 \mathrm{U}$ per $\mathrm{kg}$ of insulin are given in Table III.

The plasma sugar fell to a mean minimal value of $36 \pm 8.3 \mathrm{mg}$ per $100 \mathrm{ml}$, which is not significantly different from that found in control subjects given the same dose of insulin and reported previously (14). After the initial fall, however, the plasma sugar failed to rise normally in several of the patients. Thus the mean recovery index of the group $(217 \pm 34)$ was significantly lower ( $p<0.001$ ) than the value found in control subjects given a similar dose of insulin and approximated the value found in the control group given $0.15 \mathrm{U}$ per $\mathrm{kg}$. The plasma sugar recovery index

TABLE III

The plasma sugar, FFA, cortisol, and growth hormone response to insulin (0.10 U per kg) in patients with hypothalamic or pituitary hypofunction*

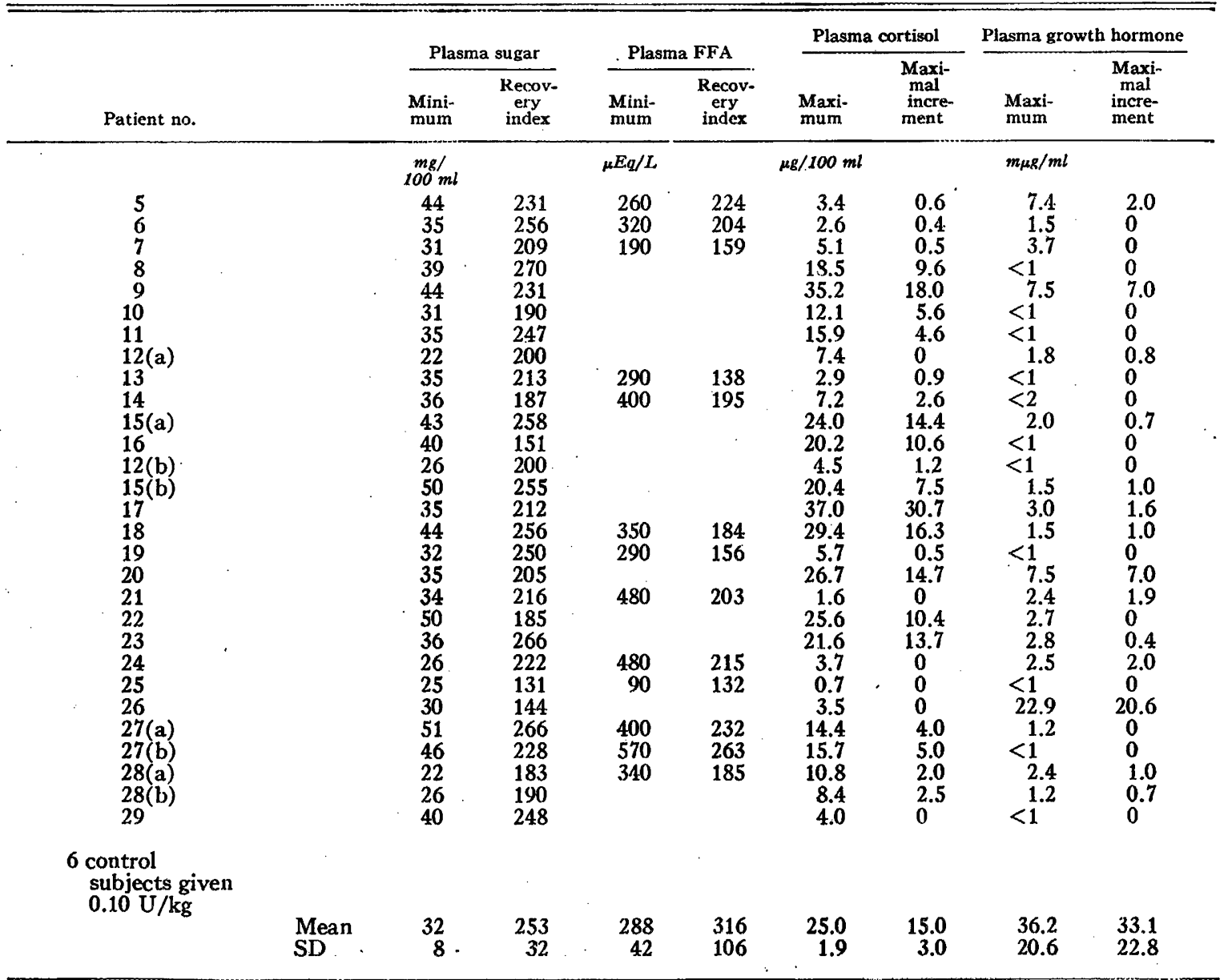

* See footnotes to Table II. 
TABLE IV

The plasma sugar, cortisol, and growth hormone response to insulin $(0.10 \mathrm{U}$ per $\mathrm{kg})$ in patients with anorexia nervosa*

\begin{tabular}{|c|c|c|c|c|c|c|}
\hline \multirow[b]{2}{*}{$\begin{array}{l}\text { Patient } \\
\text { no. }\end{array}$} & \multicolumn{2}{|c|}{ Plasma sugar } & \multicolumn{2}{|c|}{ Plasma cortisol } & \multicolumn{2}{|c|}{$\begin{array}{c}\text { Plasma growth } \\
\text { hormone }\end{array}$} \\
\hline & $\begin{array}{l}\text { Mini- } \\
\text { mum }\end{array}$ & $\begin{array}{c}\text { Recov- } \\
\text { ery } \\
\text { index }\end{array}$ & $\underset{\text { mumi- }}{\text { Maxi }}$ & $\begin{array}{c}\text { Maxi- } \\
\text { mal } \\
\text { incre- } \\
\text { ment }\end{array}$ & $\begin{array}{l}\text { Maxi- } \\
\text { mum }\end{array}$ & $\begin{array}{c}\text { Maxi- } \\
\text { mal } \\
\text { incre- } \\
\text { ment }\end{array}$ \\
\hline \multicolumn{3}{|c|}{$\mathrm{mg} / 100 \mathrm{ml}$} & $\mu \mathrm{g} / 100 \mathrm{ml}$ & \multicolumn{3}{|c|}{$m \mu g / 100 \mathrm{ml}$} \\
\hline 30 & 10 & 279 & 18.0 & 0 & 15.4 & 12.7 \\
\hline 31 & 36 & 187 & 31.2 & 10.1 & 14.6 & 0.6 \\
\hline 32 & 26 & 151 & 21.1 & 3.6 & 9.7 & 2.7 \\
\hline 33 & 41 & 224 & 31.3 & 11.3 & 13.4 & 10.0 \\
\hline 34 & 44 & 250 & 26.5 & 7.8 & 25.8 & 11.3 \\
\hline Mean & 31 & 218 & 25.6 & 6.6 & 15.8 & 7.5 \\
\hline SD & 14 & 51 & 3.3 & 4.7 & 6.0 & 5.4 \\
\hline
\end{tabular}

* See footnotes to Table II.

for each individual did not correlate with the respective responses in plasma cortisol or growth hormone, but there was a significant correlation $(r=0.50, p<0.05)$ between the resting level of plasma cortisol and the subsequent response of the plasma sugar to insulin. The results in individual patients emphasize the disparity that was occasionally found between the plasma cortisol and the plasma sugar responses. Thus Patients 16 and 17, despite a normal adrenocortical response, showed an impaired plasma sugar recovery index, whereas in Patients 6 and 27 the reverse was found. The presence or absence of a normal plasma sugar rise was not related to the growth hormone response, since this was reduced in all these patients with the exception of No. 26.

The plasma FFA response to insulin was consistently abnormal, the recovery phase being delayed (Figure 1). Thus the mean recovery index in this group was $192 \pm 38$ as compared with the value of $286 \pm 67$ found in control subjects given a larger dose of insulin (viz., $0.15 \mathrm{U}$ per $\mathrm{kg}$ ).

The adrenocortical response to insulin-induced hypoglycemia was normal in nine patients (No. 8, 9,15 to $18,20,22$, and 23 ) and impaired in the remainder. All the patients, with the exception of No. 26, had an impaired or absent growth hormone response.

In patients with anorexia nervosa. The results obtained in this group of patients after the injection of $0.10 \mathrm{U}$ per $\mathrm{kg}$ of insulin are summarized in Table IV.

In addition to having a low resting level of plasma sugar, these patients showed increased insulin sensitivity. Thus their mean recovery index was similar to the value found in the group of patients with hypothalamic or pituitary hypofunction. Three of these patients (No. 31, 33, and 34) had a normal plasma cortisol, and three (No. 30, 33, and 34) had a normal growth hormone increment during the test. The failure of these two hormones to increase normally in the remaining patients may have been partially related to the high resting levels. However, the maximal plasma cortisol level found during the test in one ( $\mathrm{Pa}$ tient 30) and the maximal growth hormone level in three (Patients 31 to 33 ) also failed to reach the normal range.

\section{A comparison of the plasma cortisol response to insulin with other tests of adrenal or pituitary- adrenal function}

The mean resting levels of urinary $17-\mathrm{OHCS}$ and the urinary steroid response to metyrapone together with the plasma cortisol response to ACTH and to insulin-induced hypoglycemia for the individual patients with pituitary or hypothalamic dysfunction are given in Table V. This Table also includes the range of values found in control subjects.

The patients can be divided into three groups on the basis of these findings. Thus in one group consisting of 13 patients (No. 1 to $4,8,9,15$ to 18 , 20,22 , and 23) all the parameters measured were normal, whereas in another group of 12 patients (No. 5 to $7,12 \mathrm{~b}$ to $14,19,21,24$ to 26 , and 29 ) they were below the normal range. In the third group, which consisted of three patients (No. 10 to 12a), with nonfunctioning pituitary tumors and two (No. 27 and 28) with hypothalamic dysfunction, there was a normal adrenal response to ACTH but an impaired or absent response to metyrapone and insulin. One of these patients (No. 11) developed the signs and symptoms of acute adrenocortical insufficiency during an airencephalogram despite normal resting levels of plasma cortisol and a normal 17-OHCS excretion.

\section{A comparison of the growth hormone response to insulin with other tests of pituitary function}

A qualitative assessment of pituitary function for $\mathrm{ADH}$, growth hormone, ACTH, TSH, and gonadotropin in each patient with hypothalamic or 
pituitary dysfunction is given in Table VI. Ideally a quantitative measurement is required both for the ability of the pituitary to synthesize each hormone and its ability to release normal amounts when required. The assessments shown vary in the extent to which they approach these ideals. The use of the term "secretion" in discussing assessments is subject to these provisos.

Growth hormone secretion was markedly increased in the patients with untreated acromegaly and was absent or impaired in the remaining pa- tients with hypothalamic or pituitary dysfunction, with the exception of Patient 26. This patient was of particular interest, since she appeared to have a single defect of ACTH production. Thus she presented with adrenocortical insufficiency and low plasma cortisol and urinary 17-hydroxycorticosteroid levels. Although she showed an adrenal response to ACTH, there was no response to metyrapone or to insulin-induced hypoglycemia. Thyroid function and ability to respond to fluid deprivation were normal, and she was unique

TABLE $V$

Comparison of the plasma cortisol response to insulin and other tests of pituitary-adremal function*

\begin{tabular}{|c|c|c|c|c|c|}
\hline Patient no. & Category & $\begin{array}{c}\text { Mean } \\
\text { resting } \\
\text { urinary } \\
\text { 17-OHCS }\end{array}$ & $\begin{array}{c}\text { Plasma } \\
\text { cortisol } \\
\text { after } \\
120 \text { minutes } \\
\text { maximal } \\
\text { stimulation } \\
\text { with ACTH }\end{array}$ & $\begin{array}{c}\text { Maximal } \\
\text { urinary } \\
\text { 17-OHCS } \\
\text { increment } \\
\text { with } \\
\text { metyrapone }\end{array}$ & $\begin{array}{c}\text { Maximal } \\
\text { plasma } \\
\text { cortisol } \\
\text { increment } \\
\text { with insulin }\end{array}$ \\
\hline $\begin{array}{l}1 \\
2 \\
3 \\
4\end{array}$ & Acromegaly (untreated) & $\begin{array}{c}m g / 24 \text { hours } \\
12.4 \\
15.8 \\
13.5 \\
10.9\end{array}$ & $\begin{array}{l}\mu g / 100 \mathrm{ml} \\
26.8 \\
40.5 \\
29.0 \\
34.8\end{array}$ & $\begin{array}{c}m g / 24 \text { hours } \\
\\
12.2 \\
12.2 \\
15.1\end{array}$ & $\begin{array}{c}\mu g / 100 \mathrm{ml} \\
13.0 \\
13.4 \\
7.9 \\
15.9\end{array}$ \\
\hline $\begin{array}{l}5 \\
6 \\
7\end{array}$ & $\begin{array}{l}\text { Acromegaly, } \\
\text { posthypophysectomy }\end{array}$ & $\begin{array}{l}7.1 \\
5.2 \\
4.6\end{array}$ & $\begin{array}{r}7.8 \\
9.3 \\
14.4\end{array}$ & $\begin{array}{l}3.8 \\
0.8 \\
3.6\end{array}$ & $\begin{array}{l}0.6 \\
0.4 \\
0.5\end{array}$ \\
\hline $\begin{array}{l}8 \\
9 \\
10 \\
11 \\
12(a) \\
13 \\
14 \\
15(a) \\
16\end{array}$ & $\begin{array}{l}\text { Chromophobe adenoma } \\
\text { or craniopharyngioma } \\
\text { (untreated) }\end{array}$ & $\begin{array}{r}12.1 \\
11.2 \\
5.9 \\
10.5 \\
2.7 \\
4.5 \\
4.5 \\
13.8 \\
14.4\end{array}$ & $\begin{array}{r}31.3 \\
58.4 \\
36.0 \\
34.5 \\
29.4 \\
12.6 \\
9.6 \\
27.6 \\
28.3\end{array}$ & $\begin{array}{c}31.2 \\
28.0 \\
3.3 \\
6.0 \\
0 \\
4.7 \\
0 \\
13.9\end{array}$ & $\begin{array}{r}9.6 \\
18.0 \\
5.6 \\
4.6 \\
0 \\
0.9 \\
2.6 \\
14.4 \\
10.6\end{array}$ \\
\hline $\begin{array}{l}12(\mathrm{~b}) \\
15(\mathrm{~b}) \\
17 \\
18 \\
19 \\
20 \\
21 \\
22 \\
23\end{array}$ & $\begin{array}{l}\text { Chromophobe adenoma } \\
\text { or craniopharyngioma, } \\
\text { posthypophysectomy }\end{array}$ & $\begin{array}{r}2.9 \\
12.0 \\
8.5 \\
14.5 \\
3.8 \\
10.0 \\
3.5 \\
13.1 \\
15.6\end{array}$ & $\begin{array}{l}30.1 \\
45.5 \\
\\
14.7 \\
41.2 \\
19.8 \\
36.3 \\
47.5\end{array}$ & $\begin{array}{r}15.7 \\
21.4 \\
4.3 \\
15.2 \\
0.7 \\
2.3 .0 \\
24.3\end{array}$ & $\begin{array}{c}1.2 \\
7.5 \\
30.7 \\
29.4 \\
0.5 \\
14.7 \\
0 \\
10.4 \\
13.7\end{array}$ \\
\hline $\begin{array}{l}24 \\
25\end{array}$ & Sheehan's syndrome. & $\begin{array}{l}2.6 \\
2.0\end{array}$ & $\begin{array}{l}8.9 \\
4.2\end{array}$ & $\begin{array}{l}3.8 \\
4.4\end{array}$ & $\begin{array}{l}0 \\
0\end{array}$ \\
\hline 26 & Isolated pituitary defect & 1.9 & 12.0 & 4.8 & 0 \\
\hline \multirow[t]{2}{*}{$\begin{array}{l}27 \\
28 \\
29\end{array}$} & Hypothalamic dysfunction & $\begin{array}{r}10.6 \\
3.9 \\
4.3\end{array}$ & $\begin{array}{l}30.8 \\
49.0 \\
19.0\end{array}$ & $\begin{array}{l}9.9 \\
4.4 \\
5.6\end{array}$ & $\begin{array}{l}5.0 \\
0.4 \\
0\end{array}$ \\
\hline & $\begin{array}{r}\text { n } \\
\text { Mean } \\
\text { Control subjects SD } \\
\text { Range }\end{array}$ & $\begin{array}{l}96 \\
12.2 \\
3.08 \\
4.8- \\
18.7\end{array}$ & $\begin{array}{l}58 \\
38.0 \\
8.0 \\
26.8 \\
55.5\end{array}$ & $\begin{array}{c}29 \\
23.9 \\
8.2 \\
10.8- \\
37.6\end{array}$ & $\begin{array}{l}\text { See Tables II } \\
\text { and III }\end{array}$ \\
\hline
\end{tabular}

* 17-OHCS $=17$-hydroxycorticosteroid; ACTH = adrénocorticotropin. 
TABLE VI

Assessment of pituitary function*

\begin{tabular}{|c|c|c|c|c|c|c|}
\hline Patient no. & Category & ADH & HGH & АстH & TSH & $\begin{array}{c}\text { Gonado- } \\
\text { tropins }\end{array}$ \\
\hline $\begin{array}{l}1 \\
2 \\
3 \\
4\end{array}$ & Acromegaly (untreated) & $\begin{array}{l}\mathbf{N} \\
\mathbf{N} \\
\mathbf{N} \\
\mathbf{N}\end{array}$ & $\begin{array}{l}\text { I } \\
\text { I } \\
\text { I } \\
\text { I }\end{array}$ & $\begin{array}{l}\mathbf{N} \\
\mathbf{N} \\
\mathbf{N}\end{array}$ & $\begin{array}{l}\mathbf{N} \\
N \\
N \\
N\end{array}$ & $\begin{array}{l}\text { Rd. } \\
\text { N } \\
\text { Rd. } \\
\text { N. }\end{array}$ \\
\hline $\begin{array}{l}5 \\
6 \\
7\end{array}$ & $\begin{array}{l}\text { Acromegaly, } \\
\text { posthypophysectomy }\end{array}$ & $\begin{array}{l}N \\
N \\
N\end{array}$ & $\begin{array}{l}\text { Rd. } \\
\text { Rd. } \\
\text { Rd. }\end{array}$ & $\begin{array}{l}\text { Rd. } \\
\text { Rd. } \\
\text { Rd. }\end{array}$ & $\begin{array}{l}\text { Rd. } \\
\text { Rd. } \\
\text { N }\end{array}$ & $\begin{array}{l}\text { Rd. } \\
\text { Rd. } \\
\text { N }\end{array}$ \\
\hline $\begin{array}{l}8 \\
9 \\
10 \\
11 \\
12(\mathrm{a}) \\
13 \\
14 \\
15(\mathrm{a}) \\
16\end{array}$ & $\begin{array}{l}\text { Chromophobe adenoma } \\
\text { or craniopharyngioma } \\
\text { (untreated) }\end{array}$ & $\begin{array}{l}\mathbf{N} \\
\mathbf{N} \\
\mathbf{N} \\
\mathbf{N} \\
\mathbf{N} \\
\mathbf{N} \\
\mathbf{N} \\
\mathbf{N} \\
\mathbf{N}\end{array}$ & $\begin{array}{l}\text { Rd. } \\
\text { Rd. } \\
\text { Rd. } \\
\text { Rd. } \\
\text { Rd. } \\
\text { Rd. } \\
\text { Rd. } \\
\text { Rd. } \\
\text { Rd. }\end{array}$ & $\begin{array}{l}\text { Rd. } \\
\text { N } \\
\text { Rd. } \\
\text { Rd. } \\
\text { Rd. } \\
\text { Rd. } \\
\text { Rd. } \\
\text { N } \\
\text { N }\end{array}$ & $\begin{array}{l}\mathrm{N} \\
\mathrm{N} \\
\mathrm{Rd} . \\
\mathrm{Rd} . \\
\text { Rd. } \\
\text { Rd. } \\
\text { Rd. } \\
\mathbf{N} \\
\mathbf{N}\end{array}$ & $\begin{array}{l}\text { Rd. } \\
\text { Rd. } \\
\text { Rd. } \\
\text { Rd. } \\
\text { Rd } \\
\text { Rd. } \\
\text { Rd. } \\
\text { N } \\
\text { N }\end{array}$ \\
\hline $\begin{array}{l}12(\mathrm{~b}) \\
15(\mathrm{~b}) \\
17 \\
18 \\
19 \\
20 \\
21 \\
22 \\
23\end{array}$ & $\begin{array}{l}\text { Chromophobe adenoma } \\
\text { or craniopharyngioma, } \\
\text { posthypophysectomy }\end{array}$ & $\begin{array}{l}\mathrm{Rd} . \\
\mathbf{N} \\
\mathbf{N} \\
\mathbf{N} \\
\mathrm{Rd} . \\
\mathbf{N} \\
\mathbf{N} \\
\mathbf{N} \\
\mathbf{N}\end{array}$ & $\begin{array}{l}\text { Rd. } \\
\text { Rd. } \\
\text { Rd. } \\
\text { Rd. } \\
\text { Rd. } \\
\text { Rd. } \\
\text { Rd. } \\
\text { Rd. } \\
\text { Rd. }\end{array}$ & $\begin{array}{l}\text { Rd. } \\
\mathbf{N} \\
\mathbf{N} \\
\mathrm{N} \\
\mathrm{Rd} . \\
\mathrm{Rd} . \\
\mathbf{N} \\
\mathbf{N} \\
\mathrm{N}\end{array}$ & $\begin{array}{l}\text { Rd. } \\
\text { N } \\
\text { Rd. } \\
\text { N } \\
\text { Rd. } \\
\text { Rd. } \\
\text { N } \\
\text { N } \\
\text { N }\end{array}$ & $\begin{array}{l}\text { Rd. } \\
\text { N } \\
\text { Rd. } \\
\text { Rd. } \\
\text { Rd. } \\
\text { Rd. } \\
\text { N } \\
\text { N } \\
\text { N }\end{array}$ \\
\hline $\begin{array}{l}24 \\
25\end{array}$ & Sheehan's syndrome & $\stackrel{N}{N}$ & $\begin{array}{l}\text { Rd. } \\
\text { Rd. }\end{array}$ & $\begin{array}{l}\text { Rd. } \\
\text { Rd. }\end{array}$ & $\stackrel{N}{N}$ & $\begin{array}{l}\text { Rd. } \\
\text { Rd. }\end{array}$ \\
\hline 26 & Isolated pituitary defect & $\mathrm{N}$ & $\mathrm{N}$ & Rd. & $N$ & $N$ \\
\hline $\begin{array}{l}27 \\
28 \\
29\end{array}$ & Hypothalamic dysfunction & $\begin{array}{l}\text { Rd. } \\
\text { Rd. } \\
\text { Rd. }\end{array}$ & $\begin{array}{l}\text { Rd. } \\
\text { Rd. } \\
\text { Rd. }\end{array}$ & $\begin{array}{l}\text { Rd. } \\
\text { Rd. } \\
\text { Rd. }\end{array}$ & $\begin{array}{l}\text { Rd. } \\
\text { R } \\
\text { Rd. }\end{array}$ & $\begin{array}{l}\text { Rd. } \\
\text { Rd. } \\
\text { Rd. }\end{array}$ \\
\hline
\end{tabular}

* $\mathrm{ADH}=$ antidiuretic hormone; $\mathrm{HGH}=$ growth hormone; $\mathrm{AC}$ TH $=$ corticotropin; $\mathrm{TSH}=$ thyroid-stimulating hormone. Function assessed as increased $(\mathrm{I})$, normal $(\mathrm{N})$, or reduced (Rd.).

among the patients with pituitary hypofunction in having a normal growth hormone response to insulin. Institution of cortisol therapy resulted in complete recovery and a return of regular menstrual periods.

Defects of ADH secretion were found in the three patients with hypothalamic dysfunction, but were limited to two hypophysectomized patients in the group with primary pituitary abnormalities.

Twenty-one patients in the present investigation had evidence of gonadotropin deficiency, and secondary hypogonadism was second only to defects of growth hormone secretion as the most common abnormality of pituitary function. This loss of gonadotropic function was not necessarily associated with an inability of the pituitary to secrete ACTH and TSH (viz., No. 3, 7 to 9, 17, 18, 24,25 , and 28). A consistent finding in the re- maining eight patients (with the exception of No. 26, whose gonadotropic function was normal) was that ACTH and TSH functions were also unimpaired.

In 12 patients, including five who had had a hypophysectomy, pituitary function in relation to both ACTH and TSH was normal, whereas in 12 the secretion of both these hormones was impaired. In the remainder ACTH function was more frequently defective than TSH function, five patients having impairment of ACTH with normal TSH secretion (No. 7, 8, 24, 25, and 28), whereas only one patient (No. 17) showed the reverse of these findings.

\section{Discussion}

It is becoming increasingly apparent that in the investigation of endocrine function, more useful 
information can be obtained with dynamic tests than by basal plasma or urinary assays. Thus although resting growth hormone levels are usually markedly elevated in patients with acromegaly, this determination is of little diagnostic value in patients with hypothalamic or pituitary hypofunction because the majority of normal subjects at rest after overnight fasting also have undetectable growth hormone levels with the sensitivity of the method used, set at $>1 \mathrm{~m} \mu \mathrm{g}$ per $\mathrm{ml}$ (14). Similarly the determination of resting plasma cortisol is of limited diagnostic use, many patients in our study having levels within the normal range. These findings emphasize the need to employ a procedure that stimulates pituitary secretion in investigating such patients.

Tests based on the blood sugar response to insulin have been widely used for this purpose. Thus patients with acromegaly have been shown to be resistant to the hypoglycemic action of insulin (17); the four patients with untreated acromegaly in the present study required $0.30 \mathrm{U}$ of insulin per $\mathrm{kg}$ to produce a response similar to that found in control subjects given half this amount. The increased insulin sensitivity found in hypopituitarism (18) or hypothalamic dysfunction (19) would appear to be of less diagnostic value, since some patients in the present study, who had definite endocrine hypofunction, showed a normal plasma sugar response to insulin. A further disadvantage is that many factors other than pituitary and hypothalamic function influence this response. Thus a variety of clinical conditions, such as primary adrenocortical insufficiency and malnutrition, which enter into the differential diagnosis of hypopituitarism, also result in increased insulin sensitivity $(18,20)$. The lack of specificity of the routine insulin-sensitivity test is overcome if simultaneous determinations of plasma cortisol and growth hormone levels are made, since their normal response depends on the integrity of the hypothalamus and pituitary.

Many clinicians are reluctant to perform insulin tolerance tests in patients suspected of having hypopituitarism (21). In our experience the value of the present test far outweighs any possible risks provided that the safeguards outlined previously (14) are undertaken and that the amount of insulin injected is related to the tentative diagnosis.
In the cases of hypopituitarism studied the growth hormone response to insulin was absent or impaired. Growth hormone production, as assessed in the present investigation, was affected before that of any other pituitary hormone, and the findings of a normal growth hormone rise would appear to exclude a diagnosis of pituitary hypofunction except for the rare cases with a single pituitary hormone defect. The determination of growth hormone levels after the injection of insulin does not appear, however, to offer any advantage as compared with the measurement of resting values in the diagnosis of patients suspected of having acromegaly. Thus in the present study, as previously reported (22), some acromegalic patients responded with a further rise in growth hormone, whereas others did not.

Three of our patients were considered to have primary hypothalamic rather than a pituitary disorder. They showed increased sensitivity to the hypoglycemic action of insulin together with an impaired or absent cortisol and growth hormone response. The importance of the hypothalamus in controlling the release of growth hormone from the pituitary after the injection of insulin may be inferred from the demonstration that stalk secretion abolishes the growth hormone response to insulin (5), whereas destruction of the anterior part of the ventral hypothalamic nucleus in squirrel monkeys decreases the growth hormone response to hypoglycemia without affecting significantly the resting levels (23). The finding that pituitary autotransplantation in the rat results in a markedly reduced rate of growth (24) is also of significance to the present findings that the two patients with hypothalamic dysfunction dating from childhood were both dwarfed.

Graded hypophysectomy in the dog results in a sequential loss of pituitary function in which gonadotropin production is impaired before that of TSH, which is then followed by loss of ACTH production (25). Similar findings have been reported in patients with a variety of pituitary lesions $(26,27)$, although evidence of secondary adrenal impairment frequently precedes that of secondary hypothyroidism in patients with chromophobe adenomas (28). On the basis of the present investigation the order in which the pituitary secretion of hormones is most commonly impaired, other than in acromegaly, is growth hor- 
mone, gonadotropins, ACTH, TSH, and $\mathrm{ADH}$, respectively. However, this order may reflect the differences in the precision and sensitivity of the methods employed for each hormonal assessment. The patients with hypothalmic dysfunction differed from the pituitary group only in the frequency with which they had diabetes insipidus.

One patient in the present study (No. 26) appeared to have a single pituitary defect, a failure to produce ACTH. She presented with secondary adrenocortical insufficiency, having an adequate adrenal response to exogenous ACTH but no response to metyrapone or to insulin-induced hypoglycemia. Other pituitary function tests were normal, and she was unique among the patients with hypothalamic or pituitary hypofunction in having a normal growth hormone rise during her test. Two similar cases have been reported (29) who, despite an inability to produce ACTH, showed a normal growth hormone response to insulin.

Normally insulin administration is associated with a prompt fall of plasma FFA values followed by their rapid return to, or above, preinsulin levels. In patients with hypothalamic or pituitary hypofunction the recovery phase of this response was found to be consistently and markedly impaired. This difference from the control group appeared to provide a more sensitive index of hypofunction than did the extent or duration of the insulin-induced hypoglycemia, suggesting that plasma FFA levels are more directly and exclusively under pituitary control than plasma sugar levels. Pituitary fractions effective in mobilizing fatty acids from adipose tissue include growth hormone, ACTH, and TSH (30). The present findings support the view that in man growth hormone may be of major importance in this respect $(31,32)$. Thus in the patients with hypothalamic or pituitary hypofunction, impairment of the normal FFA recovery phase was consistently associated with a failure of the normal growth hormone response to insulin, whereas in the patients with untreated acromegaly the extent of the FFA recovery appeared to depend on the extent of the growth hormone rise. If the presence or absence of a normal FFA recovery phase after insulin is consistently shown to be related to growth hormone, then their determination might prove of value as an indirect method of assessing the growth hormone response, which requires more elaborate technical facilities. The impaired recovery of plasma FFA values after insulin in patients with hypothalamic or pituitary dysfunction is associated with an impaired growth hormone response. The interpretation given above must have reservations, since the increase in plasma FFA levels after the injection of growth hormone is not apparent until after $1 \frac{1}{2}$ to 2 hours (31). Forearm studies, however, have shown a more rapid response (32).

The determination of plasma cortisol values throughout the test in patients with hypothalamic or pituitary disorders has less diagnostic significance than the determination of growth hormone levels, since several patients in the present study showed a normal response. It has great value, however, in determining whether maintenance steroid therapy is required in patients with pituitary dysfunction. Such subjects are free of the risk of developing acute adrenal insufficiency only if, in addition to being able to maintain an adequate adrenal output at rest, they are also able to increase this output in response to the. stress, for example, of trauma, surgery, or infection.

The plasma cortisol response to insulin-induced hypoglycemia was compared with the adrenal response to maximal stimulation with corticotropin and the 17-OHCS response to metyrapone. The patients with hypothalamic or pituitary hypofunction could be categorized into three groups on the basis of these results. In one group all three tests were normal, whereas in another all three were impaired. The third and smallest group had an impaired or absent response to metyrapone and insulin, but a normal response to ACTH. The latter result shows that they had not developed significant adrenal atrophy. Apparently their degree of hypothalamic or pituitary damage was such that the amount of functioning tissue, although capable of maintaining adequate adrenal activity at rest, was not capable of increasing the output of corticotropin-releasing factor or ACTH, respectively, in response to stress. These patients are of especial clinical significance because of the risk that their defect may not be recognized. $\mathrm{Pa}$ tient 11 exemplifies this, since his urinary steroid excretion and plasma cortisol levels lay within the normal range, and he had a normal adrenal re- 
sponse to exogenous ACTH but an air-encephalogram precipitated the signs and symptoms of acute adrenal insufficiency. In our experience basing the need for maintenance steroid therapy on the presence or absence of a normal plasma cortisol response to insulin-induced hypoglycemia militates against this risk. Although the use of metyrapone may also be of value in this respect, such tests have the disadvantage of taking several days to perform and of assessing "feedback" rather than "stress" control mechanisms.

The patients in the present study who had had a hypophysectomy had all been placed routinely on maintenance doses of cortisol at the time of their operation. More than half these patients appear to have had adequate amounts of functioning pituitary tissue left in situ to maintain adrenal function both at rest and during periods of stress, as judged by their response to insulin-induced hypoglycemia. It has been possible to withdraw steroid therapy completely in these patients without mishap.

To distinguish between anorexia nervosa and hypopituitarism may be difficult (11). Thus both groups often present with secondary amenorrhea or diminished libido and are often hypotensive. The amount of body hair is sometimes a useful differentiating sign. Frequently patients with anorexia nervosa complain of constipation and intolerance to cold, suggesting secondary hypothyroidism. Other similarities may include a flat oral glucose tolerance curve and a low urinary 17 OHCS and 17-ketosteroid excretion with an impaired urinary steroid response to ACTH (33). The measurement of the resting cortisol and growth hormone levels and their response to insulin appears to offer a simple means of differentiating these two conditions. Thus although both groups showed increased insulin sensitivity, the patients with anorexia nervosa had significantly elevated resting plasma cortisol and growth hormone values that increased normally during the test in three of the five subjects studied. The impaired response in the remaining patients suggests that prolonged starvation may result in some degree of pituitary depletion (34) that does not, however, approach the degree of hypopituitarism encountered in patients with primary hypothalamic or pituitary disorders. Glick, Roth, Yalow, and
Berson (35) have shown, also, that the measurement of plasma growth hormone levels may provide an excellent means of differentiating anorexia nervosa from hypopituitarism.

\section{Summary}

The plasma sugar, free fatty acid, cortisol, and growth hormone response to insulin in 34 patients with hypothalamic or pituitary dysfunction or anorexia nervosa has been compared with the results found in control subjects.

Patients with acromegaly were insulin resistant, but showed a normal plasma cortisol response provided a large dose was used $(0.30 \mathrm{U}$ per $\mathrm{kg})$. Some of these patients failed to show a growth hormone increment above their high resting levels during the test, and the free fatty acid response appeared to be related to the presence or absence of such a rise.

In all patients suspected of having hypothalamic or pituitary hypofunction (with the exception of one who had an isolated defect of adrenocorticotropin production) an impaired or absent growth hormone response to insulin was obtained. In some patients this was the only endocrine abnormality detected. The impairment of growth hormone secretion after insulin is of diagnostic value, since the appearance of this abnormality appears to precede evidence of gonadotropin, adrenocorticotropin, thyroid-stimulating hormone, or antidiuretic hormone deficiency. The free fatty acid response to insulin in these patients showed a consistent delay in the recovery phase. This finding proved a more sensitive index of hypofunction than did the extent and degree of the plasma sugar changes and may be of diagnostic value in hospitals without access to growth hormone determinations. The determination of plasma cortisol values throughout the insulin test had less diagnostic significance than the determination of growth hormone or free fatty acid levels, but was of value in determining whether these patients required cortisol replacement therapy. It was of particular use in detecting those patients with adequate basal adrenal function, but with limited pituitary reserve.

The response to insulin proved of value in differentiating patients with hypothalamic or pituitary hypofunction and those with anorexia nervosa. 


\section{Acknowledgments}

We wish to thank Dr. G. F. Marrian, F.R.S., and Professor A. Neuberger, F.R.S., for their interest and encouragement in this investigation and the physicians of St. Mary's Hospital for the opportunity to study their patients. We gratefully acknowledge the technical assistance of Miss C. Harris and Mrs. J. Gray, and of the technicians in the Department of Chemical Pathology, St. Mary's Hospital, under the supervision of Dr. B. Houghton, and in the Steroid Laboratory, St. Mary's Hospital, under the direction of Dr. V. H. T. James. We are especially grateful to Dr. James for his continued help and advice in relation to the steroid investigations.

\section{References}

1. Landon, J., V. Wynn, and V. H. T. James. The adrenocortical response to insulin-induced hypoglycaemia. J. Endocr. 1963, 27, 183.

2. Roth, J., S. M. Glick, R. S. Yalow, and S. A. Berson. Hypoglycemia : a potent stimulus to secretion of growth hormone. Science 1963, 140, 987.

3. Beck, P., J. H. T. Koumans, C. A. Winterling, M. F. Stcin, W. H. Daughaday, and D. M. Kipnis. Studies of insulin and growth hormone secretion in human obesity. J. Lab. clin. Med. 1964, 64, 654.

4. Hunter, W. M., and F. C. Greenwood. Studies on the secretion of human-pituitary-growth hormone. Brit. med. J. 1964, 1, 804.

5. Roth, J., S. M. Glick, R. S. Yalow, and S. A. Berson. Secretion of human growth hormone: physiologic and experimental modification. Metabolism 1963, 12,577 .

6. Frantz, A. G., and M. T. Rabkin. Human growth hormone. Clinical measurement, response to hypoglycemia and suppression by corticosteroids. New Engl. J. Med. 1964, 271, 1375.

7. Greenwood, F. C. The influence of age on growth hormone secretion and plasma levels. Proceedings of the Second International Congress of Endocrinology. London, Excerpta Medica, 1965, part 2, p. 981.

8. Langdon, R. G. In Lipide Metabolism, K. E. Bloch, Ed. New York and London, John Wiley, 1960, p. 238.

9. Di Girolamo, M., D. Rudman., M. B. Reid, and F. Seidman. Effect of pituitary hormones upon serum free fatty acid concentration of the rabbit. Endocrinology 1.961, 68, 457.

10. Winkler, B., R. Stcele., N. Altszuler, and R. C. De Bodo. Effect of growth hormone on free fatty acid metabolism. Amer. J. Physiol. 1964, 206, 174.

11. Wilson, R. R. A case of anorexia nervosa with necropsy findings and a discussion of secondary hypopituitarism. J. clin. Path. 1954, 7, 131.
12. Mogensen, E. F. Chromophobe adenoma of the pituitary gland. Acta endocr. (Kbh.) 1957, 24, 135.

13. Landon, J., V. H. T. James, and D. S. Stoker. The plasma cortisol response to lysine-vasopressin. Lancet 1965, 2, 1156.

14. Greenwood, F. C., J. Landon, and T. C. B. Stamp. The plasma sugar, free fatty acid, cortisol, and growth hormone response to insulin. I. In control subjects. J. clin. Invest. 1966, 45, 429.

15. Landon, J., V. Wynn, V. H. T. James, and J. B. Wood. Adrenal response to infused corticotropin in subjects receiving glucocorticoids. J. clin. Endocr. 1965, 25, 602 .

16. James, V. H. T., and E. Caie. Determination of urinary 17-hydroxycorticosteroids and their relation to cortisol secretion. J. clin. Endocr. 1964, 24, 180.

17. Fraser, R., G. F. Joplin, L. H. Opie, and D. Rabinowitz. The augmented insulin tolerance test for detecting insulin resistance. J. Endocr. 1962, 25, 299.

18. Fraser, R., F. Albright, and P. H. Smith. The value of the glucose tolerance test, the insulin tolerance test, and the glucose-insulin tolerance test in the diagnosis of endocrinologic disorders of glucose mctabolism. J. clin. Endocr. 1941, 1, 297.

19. Spirtos, B. N., W. R. Ingram, E. M. Bogdanove, and N. S. Halmi. Increased insulin sensitivity in rats with hypothalamic lesions, and its interpretation (abstract). J. clin. Endocr. 1954, 14, 790.

20. Williams, R. H. Textbook of Endocrinology. Philadelphia and London, W. B. Saunders, 1962, p. 715.

21. Ross, E. J. The endocrinology of pituitary tumours. Proc. roy. Soc. Med. 1961, 54, 621.

22. Hartog, M., M. A. Gaafar, B. Meisser, and T. R. Fraser. Immunoassay of serum growth hormone in acromegalic patients. Brit. med. J. 1964, 2, 1229.

23. Abrams, R. L., M. Parker, S. Blanco, S. Reichlin, and $W . H$. Daughaday. Hypothalamic regulation of growth hormone secretion (abstract). J. clin. Invest. 1964, 43, 1242.

24. Rubinstein, I.., and $\mathrm{K}$. Ahrén. Growth hormone secretion in hypophysectomised rats with multiple pituitary transplants. J. Endocr. 1965, 32, 99.

25. Ganong, W. F., and D. M. Hume. The effect of graded hypophysectomy on thyroid, gonadal and adrenocortical function in the dog. Endocrinology 1956, 59, 293.

26. Hubble, D. The course of anterior hypopituitarism. Lancet 1952, 1, 1123.

27. Jefferson, A. A. Some clinical features of the pituitary chromophobe adenomata and of the Rathké pouch cysts. Ann. roy. Coll. Surg. Engl. 1957, 21, 358.

28. Marks, V., and M. Summers. Pituitary-adrenal function in cases of pituitary tumour. Brit. med. J. 1963, 11, 155.

29. Arky, R. A., and N. Freinkel. The response of plasma human growth hormone to insulin and 
ethanol-induced hypoglycemia in two patients with "isolated adrenocorticotropic defect." Metabolism $1964,13,547$.

30. Rudman, D., S. J. Brown, and M. F. Malkin. Adipokinetic actions of adrenocorticotropin, thyroid-stimulating hormone, vasopressin, $\alpha$ - and $\beta$-melanocytestimulating hormones, fraction $\mathrm{H}$, epinephrine and norepincphrine in the rabbit, guinea pig, hamster, rat, pig and dog. Endocrinology 1963, 72, 527.

31. Raben, M. S., and C. H. Hollenberg. Effect of growth hormone on plasma fatty acids. J. clin. Invest. 1959, 38, 484.
32. Rabinowitz, D., G. A. Klassen, and K. I. Zierler. Effect of human growth hormone on muscle and adipose tissue metabolism in the forearm of man. J. clin. Invest. 1965, 44, 51 .

33. Cooke, J. N. C., V. H. T. James, J. Landon, and V. Wynn. Adrenocortical function in chronic malnutrition. Brit. med. J. 1964, 1, 662.

34. Marks, V., N. Howarth, and F. C. Greenwood. Plasma growth hormone levels in chronic starvation in man. Nature (Lond.) 1965, 208, 686.

35. Glick, S. M., J. Roth, R. S. Yalow, and S. A. Berson. The regulation of growth hormone secretion. Recent Progr. Hormone Res. 1965, 24, 241.

\section{ANNOUNCEMENT OF MEETINGS}

The American Federation for Clinical Research will hold its Twenty third Annual Meeting in Atlantic City, N. J., in the Pennsylvania Room, Haddon Hall, on Sunday, May 1, 1966, at 9:00 a.m. Joint sectional meetings with the American Society for Clinical Investigation will be held on Sunday afternoon at Chalfonte-Haddon Hall, and additional meetings sponsored by The American Federation for Clinical Research will be held on Sunday evening.

The American Society for Clinical Investigation, Inc., will hold its Fifty-èighth Annual Meeting in Atlantic City, N. J., on Monday, May 2, at 9:00 a.m., in the Pennsylvania Room, Haddon Hall, and will join The American Federation for Clinical Research in simultaneous sectional meetings on Sunday afternoon, May 1, at Chalfonte-Haddon Hall.

The Association of American Physicians will hold its Seventy-ninth Annual Meeting in Atlantic City, N. J., in the Pennsylvania Room, Haddon Hall, on Tuesday, May 3, at 9:30 a.m., and in the Carolina Room, Chalfonte, on Wednesday, May 4, at 9:30 a.m. 